\title{
Detection of Tobacco streak virus infecting sunflower by ELISA and RT-PCR method
}

BHARATI N. BHAT

Department of Plant Pathology, College of Agriculture, Prof. Jayashankar Telangana State Agricultural University, Rajendranagar, HYDERABAD (TELANGANA) INDIA

\section{ARITCLE INFO}

Received : 10.11 .2014

Revised : 07.02 .2015

Accepted : 24.02 .2015

\section{KEY WORDS :}

Sunflower necrosis disease, ELISA, RTPCR, TSV-CP gene

*Corresponding author:

Email: bharatinbhat@gmail.com

\begin{abstract}
Sunflower necrosis disease caused by Tobacco streak virus (TSV) is major threat to sunflower crop. The presence of TSV in necrosis disease affected leaf samples collected from major sunflower growing areas of Andhra Pradesh, Karnataka, Maharashtra and Tamil Nadu was confirmed by direct antigen-coated enzyme linked immunosorbent assay using TSV specific polyclonal antiserum. All the isolates showed positive reaction in ELISA test using TSV specific polyclonal antiserum, indicating the presence of TSV. The ELISA values varied from 0.57 to 1.18 as compared to the positive control i.e. TSV infected cowpea (1.59) and healthy control (0.07). Disease reaction and symptomatology of three test plants viz., cowpea cv. C-152, sunflower cv. MORDEN and Nicotiana tabacum cv. SAMSUN to these virus isolates were studied under artificial inoculated condition by sap transmission. Using primers specific to the coat protein region of TSV, RT-PCR was successful in amplifying TSV- CP gene from sunflower tissue. A DNA band of expected size (approximately $700 \mathrm{bp}$ ) was observed in all the necrosis disease affected sunflower samples collected from Maharashtra, Karnataka, Tamil Nadu and Andhra Pradesh. Characterization of the isolates of virus through cloning and sequencing may reveal the occurrence of pathotypes/serotypes from different sunflower growing locations of the country.
\end{abstract}

How to view point the article : Bhat, Bharati N. (2015). Detection of Tobacco streak virus infecting sunflower by ELISA and RT-PCR method. Internat. J. Plant Protec., 8(1) : 99-103. 